\title{
Kinetics of the reaction of compound III of horseradish peroxidase with hydrogen peroxide and NADPH
}

\author{
S. A. ADENIYI ${ }^{1 *}$, C. L. ORJIEKWE ${ }^{1}$ and S. J. JOSIAH ${ }^{2}$ \\ ${ }^{1}$ Department of Chemical Sciences, College of Natural and Applied Sciences, Igbinedion University Okada, \\ P.M.B.0006, Benin City, Edo State, Nigeria. \\ ${ }^{2}$ Department of Biochemistry, College of Medicine, Igbinedion University Okada, P.M.B.0006, Benin City, \\ Edo State, Nigeria. \\ *Corresponding author, E-mail: gokeomen@yahoo.com
}

\begin{abstract}
The kinetic study of the reaction of Compound III of horseradish peroxidase with reduced nicotinamide adenine dinucleotide phosphate (NADPH) was investigated in phosphate buffer as a function of ionic strength at $25^{\circ} \mathrm{C}$. Two successive reactions involving increase and decrease in absorbance with time were observed. Each reaction was first order with respect to the concentration of horseradish peroxidase. The observed rate constants were ionic strength dependent within the range of $0.06-0.30 \mathrm{M}$. The logarithmic values of the rate constants against the square root of the ionic strength showed that both NADPH and Compound III of horseradish peroxidase are of same ionic charges in the first reaction but different ionic charges in the second reaction.
\end{abstract}

(C) 2009 International Formulae Group. All rights reserved.

Key words: Ionic strength, rate constant, horseradish peroxidase, NADPH.

\section{INTRODUCTION}

There is a growing interest in peroxidase chemistry because of its immense importance and high distribution in biological system (Hiromi, 1979). Peroxidases are metabolizing heme enzymes that are distributed in fungal, plant and mammalian organisms (Jenzer et al., 1986). The enzymes are involved in important physiological roles such as biosynthesis of hormones stress and pathogen responses via the oxidation of various substrates at the expense of hydrogen peroxide (Tanaka et al., 2003).

The reaction between the ferric resting enzyme and hydrogen peroxide involves a two-electron oxidation to give a green enzyme intermediate known as compound I, with the heme iron oxidized to the oxyferryl state $\left(\mathrm{Fe}^{4+}=\mathrm{O}\right)$ and a $\pi$-cation radical on the porphyrin ring (Shiro et al., 1986). While the formation of compound I from the oxidation of the enzyme with hydrogen peroxide is initiated by a rapid reaction $\left(\mathrm{k}_{1} \sim 10^{7} \mathrm{M}^{-1} \mathrm{~S}^{-1}\right)$, other oxygen-binding heme proteins such as myoglobin react slowly with hydrogen peroxide $\left(\mathrm{k}_{1} \sim 10^{2} \mathrm{M}^{-1} \mathrm{~S}^{-1}\right)$ and do not form stable compound I (Morishima et al., 1986; Rodriguez-Lopez et al., 1997; Matsui et al., 1999; Egawa et al., 2000).

Penel et al. (1992) have reported that horseradish peroxidase (HRP) is an extracellular plant enzyme involved in the formation of free radical intermediates for the polymerization and cross-linking of cell wall components, for the oxidation of secondary metabolites for certain pathogenic defense reactions, and for the regulation of cell growth and differentiation. The reaction between HRP and hydrogen peroxide at a cryogenic temperature indicates the saturation kinetics 
against the hydrogen peroxide concentration, which suggests the presence of an intermediate state before the formation of compound I (Balny et al., 1987; Baek and Van Wart, 1989; 1992). In the absence of reducing substrate, hydrogen peroxide can react with compound I as an electron donor (reductant) in a catalase-like two-electron process that results in the formation of the next intermediate, compound II. Further reaction of compound II with excess hydrogen peroxide produces a red enzymatically inactive compound known as compound III (Dunford, 1991; Rodriguez-Lopez et al., 1996).

The kinetics of the reaction of compound III is governed by the concentration of hydrogen peroxide only and not by ratio of peroxide to peroxidase (George, 1953). Compound III appears to be formed directly from compound II and can be reconverted to compound II by the action of catalase (George, 1953).

Although, there are literature reports on the kinetics of the reaction of compound III with hydrogen peroxide, not much is known in literature about the effect of ionic strength on same reaction in the presence of a reducing substrate such as NADPH. The purpose of this work is to study the effect of ionic strength on the kinetics of the reaction of compound III of horseradish peroxidase with reduced nicotinamide adenine dinucleotide phosphate (NADPH) at $25^{\circ} \mathrm{C}$.

\section{MATERIALS AND METHODS \\ Materials}

Horseradish peroxidase (POD: Donor: hydrogen peroxide oxidoreductase EC.1.11. 1.7) was purchased from Sigma Chemical Company (USA) as an ammonium sulphate suspension. Hydrogen peroxide (density, 1.11 $\mathrm{g} / \mathrm{cm}^{3}$ ) was purchased from Fluka (Switzerland) and NADPH was purchased from E. Merck (Germany). Apart from the horseradish peroxidase, all other chemicals were of analytical grade and were used without further purification.

\section{Absorbance measurement \\ Absorbance measurements were done on SP8-500UV/Vis spectrophotometer fitted with a PYE Unicam recorder according to the method of Dunford 1991.}

\section{Dialysis of HRP}

Horseradish peroxidase was dialyzed extensively against distilled water before use. Dialysis affords a convenient means for removing the salt from the re-suspended protein. The dialysis bag used was boiled in water for several minutes to dissolve away the proteins present, if there was any. The enzyme was introduced into the dialysis bag through a syringe and then tied tightly at both ends. The dialysis bag was then placed in a clean 250 $\mathrm{cm}^{3}$ conical flask containing distilled water and was maintained at $4{ }^{\circ} \mathrm{C}$ to prevent denaturation of the protein. The distilled water was changed twice over a period of 48 hours at 24 hours interval.

\section{Preparation of buffer solutions}

$\mathrm{KH}_{2} \mathrm{PO}_{4}$ buffer solutions of $\mathrm{pH} 7.0$ but different ionic strengths were prepared and used for this work. $\mathrm{KNO}_{3}$ solutions were prepared and used to adjust the ionic strength of the $\mathrm{KH}_{2} \mathrm{PO}_{4}$ buffer solution to $0.06 \mathrm{M}, 0.10$ $\mathrm{M}, 0.15 \mathrm{M}, 0.20 \mathrm{M}, 0.25 \mathrm{M}$ and $0.30 \mathrm{M}$ respectively.

\section{Enzyme concentration determination}

The concentration of peroxidase was determined spectrophotometrically (Nakajima and Yamazaki, 1987) at $403 \mathrm{~nm}$ using a molar absorption coefficient of $1.02 \times 10^{5} \mathrm{M}^{-1} \cdot \mathrm{cm}^{-1}$ and was calculated to be $8.15 \times 10^{-5}$ mol.dm ${ }^{-3}$. The concentration was determined everyday since the concentration of the enzyme varies from time to time.

\section{Kinetic procedure}

The kinetic experiment was carried out according to the method described by Jenzer et al. (1986) by preparing $5 \mu \mathrm{M}$ Compound III in situ, adding a particular amount of NADPH and measuring the absorbance changes at 418 $\mathrm{nm}$ as a function of time. The experiment was conducted under the following conditions: the concentrations of $\mathrm{KH}_{2} \mathrm{PO}_{4}$ buffer solution ( $\mathrm{pH}=7.0$ ), HRP and $\mathrm{H}_{2} \mathrm{O}_{2}$ were fixed, wavelength $(418 \mathrm{~nm})$ and ionic strengths were $0.06 \mathrm{M}, 0.10 \mathrm{M}, 0.15 \mathrm{M}, 0.20 \mathrm{M}, 0.25 \mathrm{M}$ and $0.30 \mathrm{M}$. The rate constants, $\mathrm{k}$ was evaluated using Bronsted and Bjerram equation relating rate constant with ionic strength (Heys, 1969). $\log k=\log k_{\mathrm{o}}+1.018 \mathrm{Z}_{\mathrm{A}} \mathrm{Z}_{\mathrm{B}} \sqrt{\mathrm{I}}_{\mathrm{I}} \quad$ (1); where $\mathrm{Z}_{\mathrm{A}}$ and $\mathrm{Z}_{\mathrm{B}}$ are the ionic charges on the 
reactants, $\mathrm{k}_{\mathrm{o}}$ is a constant, $\mathrm{k}$ is the rate constant and $\mathrm{I}$ is the ionic strength.

\section{RESULTS AND DISCUSSION}

Table 1 shows the values of the absorbances of the enzyme solution with $\mathrm{H}_{2} \mathrm{O}_{2}$ and with NADPH at ionic strength of $0.06 \mathrm{M}$ using the SP8-500 UV/Vis Spectrophotometer at 120 seconds interval, while Tables 3 and 4 show the variation of rate constant with ionic strength for first and second reaction on the addition of $\mathrm{H}_{2} \mathrm{O}_{2}$ and NADPH respectively.

The initial reaction of horseradish peroxidase with hydrogen peroxide yields compound I of HRP. Further addition of low concentration of hydrogen peroxide results in the formation of compound II. Compound III is obtained on the addition of excess hydrogen peroxide. The studies of the rate of reaction of compound III of HRP with NADPH showed that the reaction proceeds in two stages at ionic strengths of $0.06 \mathrm{M}-0.30 \mathrm{M}$.

From figure 1, it was observed that there was a gradual increase in the absorbance with time which reaches an optimum value at 60 seconds, which corresponds to the first stage. This was followed immediately by a gradual decrease in absorbance until a steady state absorbance was reached (second stage). To be able to visualize what is happening in stages 1 and 2, the absorbance reading of $\mathrm{H}_{2} \mathrm{O}_{2}$ and NADPH was taken within a smaller time interval between $0-480$ seconds. The evaluation of the logarithmic values of absorbance against time (from table 1) is presented in table 2 and the graphs are plotted in figures 2 and 3 for first reaction and second reaction respectively. Figure 2 is a straight line graph with positive gradient corresponds to first stage, which is the reaction of compound III of horseradish with NADPH to form the intermediate compound; while figure 3 is a straight line with negative gradient corresponds to second stage which is the decomposition of the intermediate compound to form the final product (free enzyme).

The formation of intermediate compound is believed to be completed at the maximum absorbance (see figure 1), thereafter the absorbance gradually decreases due to decomposition of the intermediate to the final product (free enzyme). These results show that the compound III of horseradish peroxidase decomposes in the presence of donors such as NADPH and reacts rapidly with donors to give the free enzyme via a transient intermediate compound. No measurable amount of this intermediate compound accumulates to inhibit the activity of the peroxidase under the usual laboratory experimental conditions as claimed by George (1953).

No intermediates such as compound II of horseradish peroxidase were detected during the conversion of compound III of horseradish peroxidase to free enzyme, which is inconsistent with the result obtained by George (1953), which showed that the removal of excess hydrogen peroxide by catalase brings about a decomposition of compound III to compound II.

It is also observed from tables 3 and 4 that the rate constant increases as ionic strength increases in the first reaction but in the second reaction, the rate constant decreases as ionic strength increases. This observation according to Bronsted and Bjerram theory indicates that the ionic charges of the reacting species in first reaction have

Table 1: Absorbance value against time of $0.06 \mathrm{M}$ for (a) $\mathrm{H}_{2} \mathrm{O}_{2}$ and (b) NADPH.

\begin{tabular}{lcc}
\hline Time (Seconds) & Absorbance $\left(\mathbf{H}_{\mathbf{2}} \mathbf{O}_{2}\right)$ & Absorbance (NADPH) \\
\hline 0 & 0.419 & 0.318 \\
120 & 0.430 & 0.316 \\
240 & 0.399 & 0.293 \\
360 & 0.363 & 0.268 \\
480 & 0.333 & 0.250 \\
600 & 0.314 & 0.237 \\
720 & 0.299 & 0.299 \\
840 & 0.290 & 0.244 \\
960 & 0.286 & 0.221 \\
1080 & 0.284 & 0.218 \\
\hline
\end{tabular}




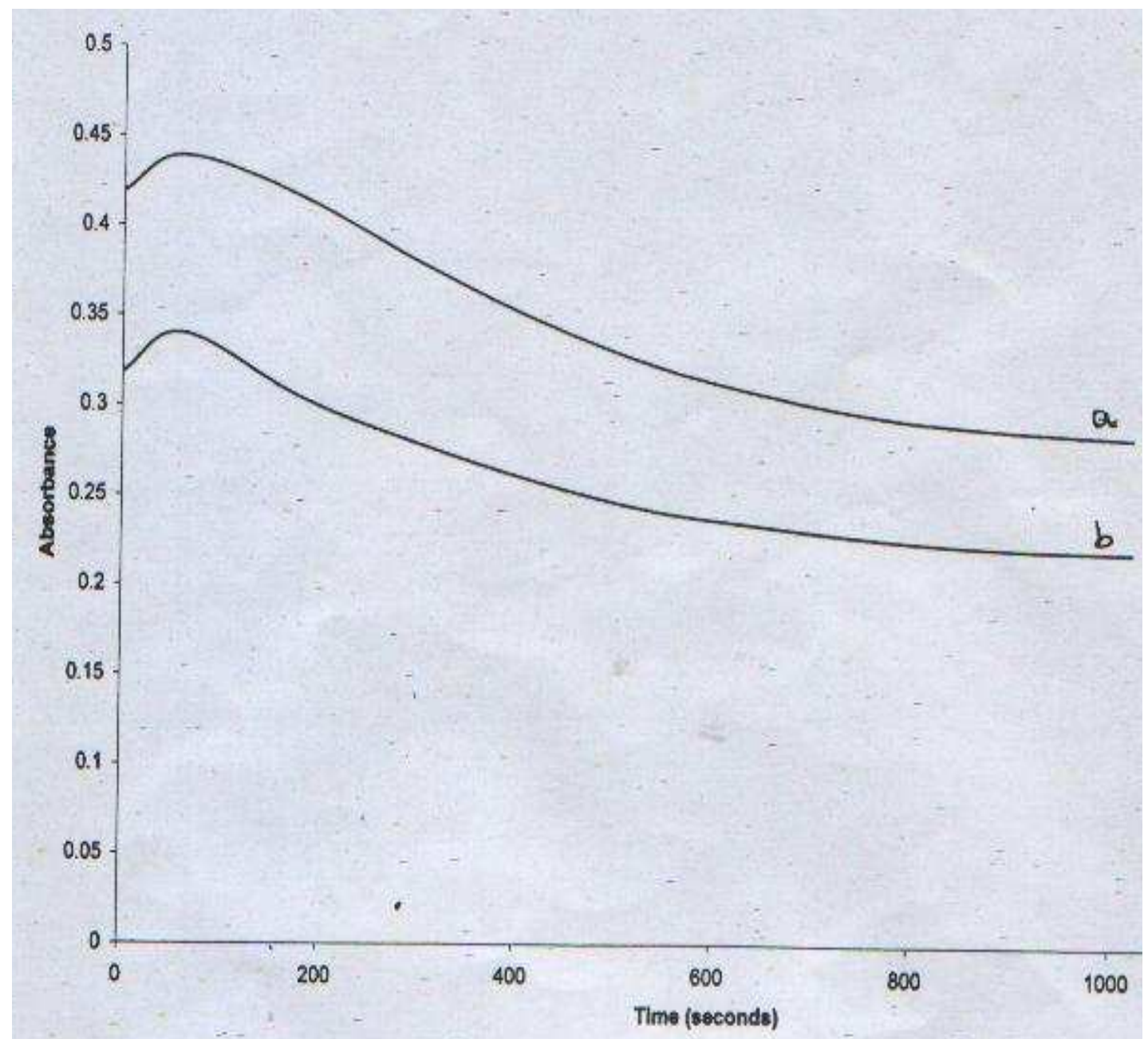

Figure 1: Plot of Absorbance against Time with (a) $\mathrm{H}_{2} \mathrm{O}_{2}$ and (b) NADPH.

Table 2: Logarithmic values of absorbance against time within $0-480$ seconds for $\mathrm{H}_{2} \mathrm{O}_{2}$ and (b) NADPH.

\begin{tabular}{|c|c|c|c|c|}
\hline \multirow{2}{*}{ Time (Seconds) } & \multicolumn{2}{|c|}{$\mathrm{H}_{2} \mathrm{O}_{2}$} & \multicolumn{2}{|c|}{ NADPH } \\
\hline & Absorbance & Iog A & Absorbance & $\log A$ \\
\hline 0 & 0.419 & -0.378 & 0.318 & -0.498 \\
\hline 30 & 0.430 & -0.367 & 0.321 & -0.493 \\
\hline \multirow[t]{2}{*}{60} & 0.439 & -0.367 & 0.322 & -0.492 \\
\hline & \multicolumn{2}{|c|}{ Second Reaction } & \multicolumn{2}{|c|}{ Second Reaction } \\
\hline 120 & 0.430 & -0.367 & 0.316 & -0.500 \\
\hline 180 & 0.416 & -0.381 & 0.304 & -0.517 \\
\hline 240 & 0.399 & -0.399 & 0.293 & -0.533 \\
\hline 300 & 0.380 & -0.420 & 0.279 & -0.554 \\
\hline 360 & 0.363 & -0.440 & 0.268 & -0.574 \\
\hline 420 & 0.348 & -0.458 & 0.258 & -0.588 \\
\hline 480 & 0.333 & -0.478 & 0.250 & -0.602 \\
\hline
\end{tabular}




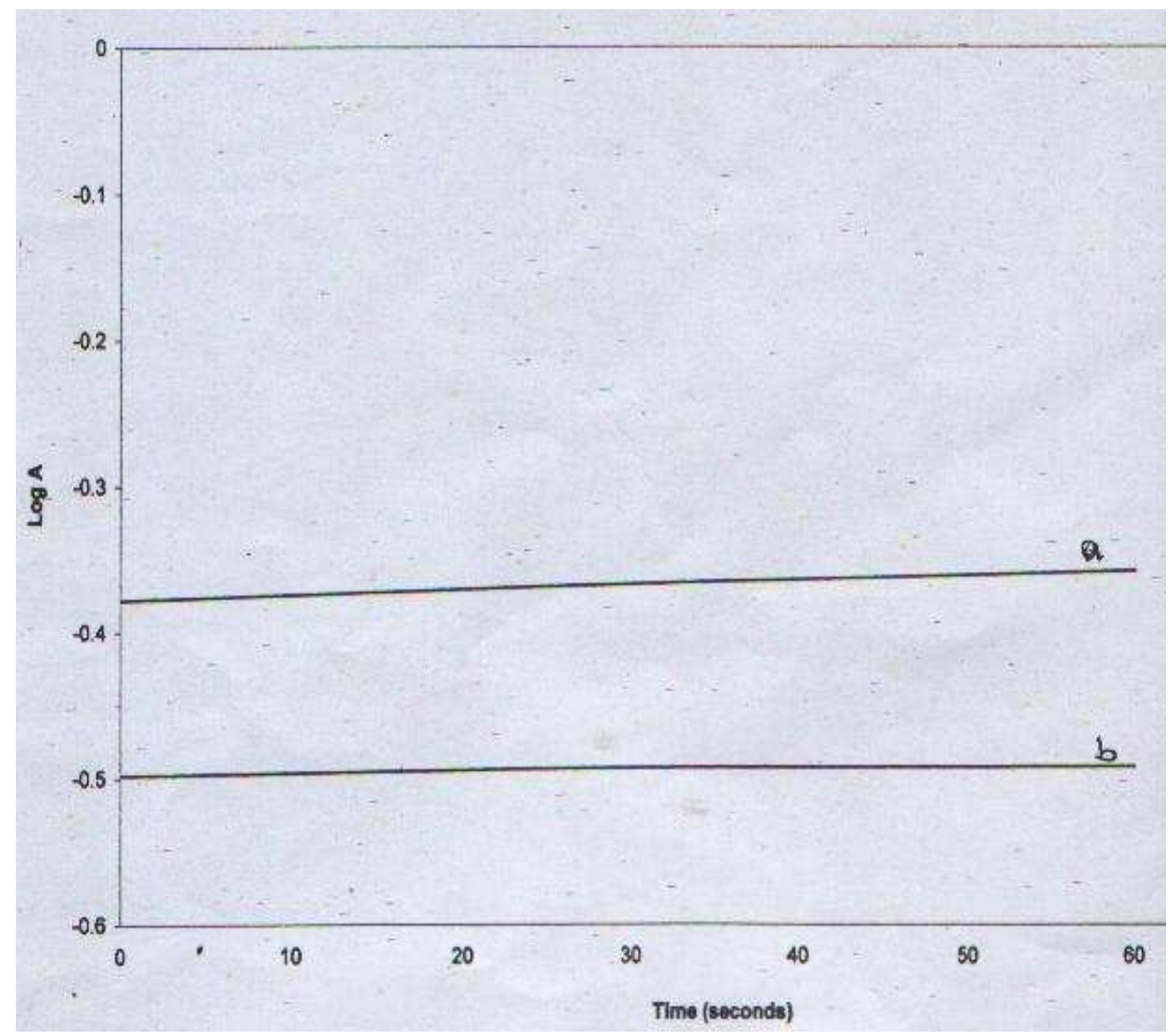

Figure 2: Plot of Log A against Time on addition of (a) $\mathrm{H}_{2} \mathrm{O}_{2}$ and (b) NADPH for $1^{\text {st }}$ reaction.

Table 3: Variation of rate constant with ionic strength on addition of (a) $\mathrm{H}_{2} \mathrm{O}_{2}$ and (b) NADPH for $1^{\text {st }}$ reaction.

\begin{tabular}{|c|c|c|c|c|c|}
\hline \multirow{2}{*}{$\begin{array}{l}\text { Ionic Strength, I } \\
\text { (M) }\end{array}$} & \multirow{2}{*}{$\sqrt{ } \mathbf{I}$} & \multirow{2}{*}{$\begin{array}{c}\mathrm{H}_{2} \mathrm{O}_{2} \\
\text { First Reaction } \\
\begin{array}{c}\text { Rate Constants, } \mathrm{k} \\
\left(\mathrm{s}^{-1}\right) \times \mathbf{1 0}^{-3}\end{array} \\
\end{array}$} & \multicolumn{3}{|c|}{$\begin{array}{c}\text { NADPH } \\
\text { First Reaction }\end{array}$} \\
\hline & & & $\log k$ & $\begin{array}{c}\text { Rate Constants, } \mathrm{k} \\
\left(\mathrm{s}^{-1}\right) \times 10^{-3} \\
\end{array}$ & $\log k$ \\
\hline 0.06 & 0.24 & 0.84 & -3.08 & 0.38 & -3.42 \\
\hline 0.10 & 0.32 & 1.38 & -2.86 & 0.54 & -3.27 \\
\hline 0.15 & 0.39 & 2.00 & -2.70 & 0.92 & -3.04 \\
\hline 0.20 & 0.45 & 2.61 & -2.58 & 1.23 & -2.91 \\
\hline 0.25 & 0.50 & 2.92 & -2.53 & 1.54 & -2.81 \\
\hline 0.30 & 0.55 & 3.92 & -2.41 & 1.84 & -2.74 \\
\hline
\end{tabular}




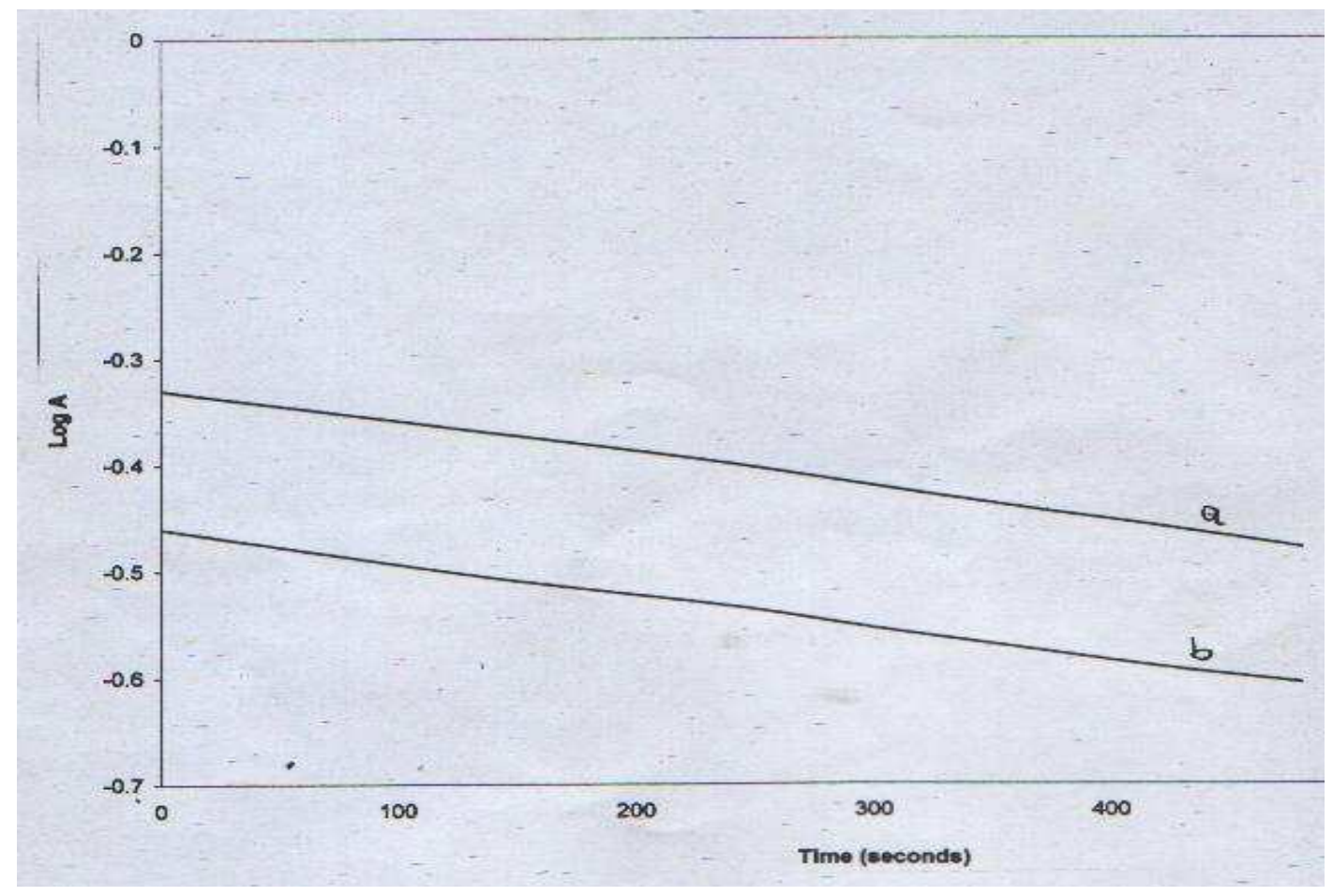

Figure 3: Plot of Log A against Time on addition of (a) $\mathrm{H}_{2} \mathrm{O}_{2}$ and (b) NADPH for $2^{\text {nd }}$ reaction.

Table 4: Variation of rate constant with ionic strength on addition of (a) $\mathrm{H}_{2} \mathrm{O}_{2}$ and (b) NADPH for $2^{\text {nd }}$ reaction.

\begin{tabular}{|c|c|c|c|c|c|}
\hline \multirow{3}{*}{$\begin{array}{l}\text { Ionic Strength, I } \\
\text { (M) }\end{array}$} & \multirow{3}{*}{$\sqrt{ } \mathbf{I}$} & \multirow{3}{*}{$\begin{array}{c}\mathrm{H}_{2} \mathrm{O}_{2} \\
\text { Second Reaction } \\
\text { Rate Constants, } \mathrm{k} \\
\left(\mathrm{s}^{-1}\right) \times \mathbf{1 0}^{-3}\end{array}$} & \multirow{2}{*}{\multicolumn{3}{|c|}{$\begin{array}{c}\text { NADPH } \\
\text { Second Reaction }\end{array}$}} \\
\hline & & & & & \\
\hline & & & $\log k$ & $\begin{array}{l}\text { Rate Constants, } \mathrm{k} \\
\qquad\left(\mathrm{s}^{-1}\right) \times 10^{-3}\end{array}$ & $\log k$ \\
\hline 0.06 & 0.24 & 7.55 & -3.12 & 7.22 & -3.41 \\
\hline 0.10 & 0.32 & 7.48 & -3.13 & 6.53 & -3.19 \\
\hline 0.15 & 0.49 & 6.85 & -3.16 & 6.01 & -3.22 \\
\hline 0.20 & 0.45 & 6.40 & -3.19 & 5.37 & -3.27 \\
\hline 0.25 & 0.50 & 6.14 & -3.21 & 4.61 & -3.34 \\
\hline 0.30 & 0.55 & 5.63 & -3.25 & 4.09 & -3.39 \\
\hline
\end{tabular}

the same sign whereas the ionic charges of the reacting species in the second reaction are of different signs, thus indicating reaction via an intermediate compound.

\section{Conclusion}

This study has shown that the reaction of compound III of horseradish peroxidase with NADPH at ionic strengths of $0.06-0.30$ $M$ proceeds via the formation of an intermediate compound. Also the experimental results in tables 3 and 4 have confirmed the theoretical conclusion of Bronsted and Bjerram on the basis of the formation of intermediate compounds. 


\section{REFERENCES}

Baek HK, Van Wart HE. 1989. Elementary steps in the formation of horseradish peroxidase compound I: direct observation of compound 0 , a new intermediate with a hyperporphyrin spectrum. Biochemistry, 28: 5714-5719.

Baek HK, Van Wart HE. 1992. Elementary steps in the formation of horseradish peroxidase with several peroxides: kinetic and thermodynamics of formation of compound 0 and compound. I. J. Am. Chem. Soc., 114: 718-725.

Balny C, Travers F, Barmanu T, Douzou P. 1987. Thermodynamics of the two step formation of horseradish peroxidase compound. I. Eur. Biophys. J., 14: 375383.

Dunford HB. 1991. Horseradish peroxidase: structure and kinetic properties. In Peroxidases in Chemistry and Biology, (Vol 2.) Everse J, Everse KE, Grisham MB (eds). CRC Press: Boca Raton, FL; $1-24$.

Egawa T, Shimada H, Ishimura Y. 2000. Formation of compound $\mathrm{I}$ in the reaction of native myoglobins with hydrogen peroxide. J. Biol. Chem., 275: 3485834866.

George P. 1953. The chemical nature of the second hydrogen peroxide compound formed by cytochrome $\mathrm{C}$ peroxidase and horseradish peroxidase. 1. Titration with reducing agents. Biochem. J., 54(2): 267276.

Heys HL. 1969. Physical Chemistry ( $3^{\text {rd }}$ edn). Pitman Press: Britain; 153-155.

Hiromi K. 1979. Kinetics of Fast Enzyme Reactions. Halsted Press: New York; 244-247.

Jenzer H, Jones W, Kohler H. 1986. On the molecular mechanism of lactoperoxidase-catalyzed hydrogen peroxide metabolism and irreversible enzyme inactivation. J. Biol. Chem., 261: 1555015556.
Matsui T, Ozaki S, Liong E, Phillips GH Jr, Watanabe Y. 1999. Effect of the location of distal histidine in the reaction of myoglobin with hydrogen peroxide. $J$. Biol. Chem., 274: 2838-2844.

Morishima I, Kurono M, Shiro Y. 1986. Presence of endogenous calcium ion in horseradish peroxidase. Elucidation of metal-binding site by substitutions of divalent and lanthanide ions for calcium and use of metal-induced NMR $\left({ }^{1} \mathrm{H}\right.$ and $\left.{ }^{113} \mathrm{Cd}\right)$ resonances. J. Biol. Chem., 261: 9391-9399.

Nakajima R, Yamazaki I. 1987. The mechanism of oxyperoxidase formation from ferryl peroxidase and hydrogen peroxide. J. Biol. Chem., 262: 2576-2581.

Penel C, Gaspar TH, Greppin H. 1992. Plant Peroxidases: 1980-1990. University of Geneva: Geneva, Switzerland; 102-108.

Rodriguez-Lopez JN, Smith AT, Thorneley RNF. 1996. Recombinant horseradish peroxidase isoenzyme $\mathrm{C}$ : The effect of distal haem cavity mutations (His $42 \rightarrow$ Leu and Arg $38 \rightarrow$ Leu) on compound I formation and substrate binding. J. Biol. Inorg. Chem., 1(2): 136142.

Rodriguez-Lopez JN, Hernández-Ruiz J, Garcia-Cánovas F, Thorneley RNF, Acosta M, Arnao MB. 1997. The inactivation and catalytic pathways of horseradish peroxidase with mChloroperoxybenzoic acid. J. Biol. Chem., 272(9): 5469-5476.

Shiro Y, Kurono M, Morishima I. 1986. Presence of endogenous calcium ion and its functional and structural regulation in horseradish peroxidase. J. Biol. Chem., 261: 9382-9390.

Tanaka M, Matsuura K, Shiro Y, Takahashi S, Ishimori K, Hori H, Morishima I. 2003. Activation of hydrogen peroxide in horseradish peroxidase occurs within 200 $\mu$ s observed by a new Freeze-Quench Device. Biophysical. J., 84: 1998-2004. 